\title{
Effect of Anticonvulsant Therapy on Serum 25-Hydroxyvitamin D Level
}

\author{
Kiyoomi Sumi, Takahiro Sugita, Tsunesuke Shimotsuji, \\ Yoshiki Seino, Takashi Mimaki and Hyakuji Yabuuchi \\ Department of Pediatrics, Osaka University Medical School, \\ Osaka 553
}

Sumr, K., Sugrta, T., Smimotsuji, T., Seino, Y., Mrmaki, T. and Yabuuchi, H. Effect of Anticonvulsant Therapy on Serum 25-Hydroxyvitamin D Level. Tohoku J. exp. Med., 1978, 125 (3), 265-269_-Serum 25-hydroxyvitamin D levels in young patients receiving anticonvulsants were assayed. They had neither retardation of physical and psychomotor development nor malnutrition. The patients treated with phenobarbital alone revealed rather high levels of serum 25-hydroxyvitamin D during 2 months after institution of the therapy, then they gradually returned to the normal level by the end of 3 to 5 months and thereafter decreased further, while a marked decrease of serum 25-hydroxyvitamin D levels was observed in patients receiving combined anticonvulsant (phenobarbital, diphenylhydantoin and others) therapy even during 1 to 2 months after initiation of the treatment. Our results suggest that the patients who have combined anticonvulsant therapy will have more tendency to suffer from osteomalacia than those who have phenobarbital alone._- serum 25-hydroxyvitamin D; phenobarbital; diphenylhydantoin

Long-term anticonvulsant therapy is known to be associated with osteomalacia presumably as a result of disturbance of vitamin D metabolism (Kruse 1968; Richen and Rowe 1970). A high incidence of osteomalacia is usually observed in the patients who had psychomotor retardation and/or physical disturbance with long-term combined anticonvulsant therapy (Teotia et al. 1973; Lifschitz and Maclaren 1973; Leonidas et al. 1973; Stamp 1974), while osteomalacia is very rare among the patients receiving phenobarbital (PB) therapy (Leonidas et al. 1973). It has also been demonstrated that serum levels of 25 -hydroxyvitamin $\mathrm{D}$ (25-OH-D), active major metabolite of vitamin $\mathrm{D}$ in serum, significantly decreased in the patients treated with single or combined anticonvulsant drugs for a long time (Stamp et al. 1972; Hahn et al. 1972; Hahn et al. 1975a; Tolman et al. 1975). However, most of these data are of the adults, of the children with mental retardation and physical disturbances, or the cases of long-term administration.

In the present paper, we investigated the serum 25-0H-D levels after institution of anticonvulsant therapy in young patients who had neither retardation of physical and psychomotor development nor malnutrition.

Received for publication, November 17, 1977. 


\section{Materiats and Methods}

Blood samples were obtained from 42 epileptics treated with $\mathrm{PB}$ alone, 24 epileptics treated with combination of $\mathrm{PB}$ and diphenylhydantoin (DPH), and 10 epileptics receiving $\mathrm{PB}, \mathrm{DPH}$ and other anticonvulsants, i.e. carbamazepine or acetazolamide. The average age of the patients was 5 years (10 months -16 years). The average duration of single $\mathrm{PB}$ administration was 7 months ( 1 month -3 years) and that of combined administration was 8 months ( 2 months -3 years). PB was administered orally in a dose of $2-8 \mathrm{mg} / \mathrm{kg} /$ day and a dose of DPH was $1.5-10 \mathrm{mg} / \mathrm{kg} /$ day. The physical and psychomotor developments of all patients were within the normal range. They had also adequate sun exposure and dietary intake of vitamin $D$. No rachitic changes were shown in their bone $x$-ray examinations.

After more than $6 \mathrm{hr}$ fasting, blood was drawn and the serum was stored at $-20^{\circ} \mathrm{C}$ until used. Serum 25-OH-D levels were assayed by the competitive protein-binding radioassay technique reported previously (Shimotsuji et al. 1976). The serum lipids were extracted with chloroform-hexan-methanol-water mixture according to Preece et al. (1974). An aliquot of the lipid extracts was prepared directly for the competitive protein-binding assay without column chromatography (rapid assay). The remainder was dissolved in chloroform-hexan mixture (1:1) and applied to a $10 \times 250 \mathrm{~mm}$ Sephadex LH-20 column (Holick and DeLuca 1971). The serum 25-OH-D values obtained by the rapid assay showed a close correlation with those determined by the preparative chromatography in the range of $17.5-176 \mathrm{ng} / \mathrm{ml}$, but they were slightly higher than those measured by the method of column chromatography $(r=0.875, n=15, y=1.16 x+0.227)$. The serum 25.0H-D levels before anticonvulsant therapy were used as the control values.

\section{Results}

Patients administered PB alone showed a marked increase of serum 25-OH-D levels within 2 months $(p<0.005)$, thereafter the levels decreased to the control values by the end of the 3rd month (Fig. 1). After 6-11 months' administration

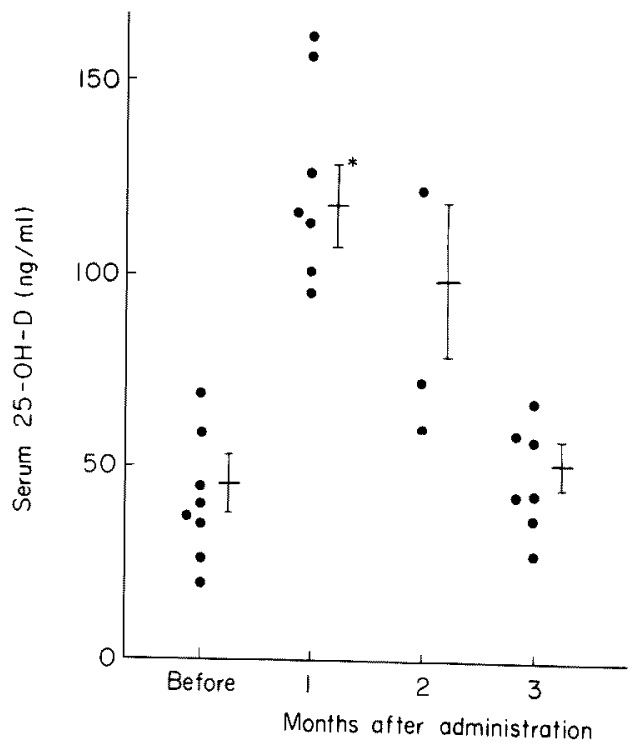

Fig. 1. Serum 25-OH-D levels of epileptic children $(n=12)$ before and after phenobarbital administration. Bars indicate meants.E.M. ${ }^{*} p<0.005$. 
TABLE 1. Serum 25-OH-D levels of patients receiving single phenobarbital $(P B)$ or both phenobarbital and diphenylhydantoin (DPH) for the anticonvulsant therapy

\begin{tabular}{|c|c|c|c|}
\hline Groups & $\begin{array}{l}\text { Number of } \\
\text { patients }\end{array}$ & $\begin{array}{l}\text { Duration of } \\
\text { therapy }\end{array}$ & $\begin{array}{c}\text { Serum 25-OH-D* } \\
\mathrm{ng} / \mathrm{ml}\end{array}$ \\
\hline Control & 23 & $\ldots$ & $46.2 \pm 5.55$ \\
\hline Single PB therapy & 11 & $1-2 \mathrm{mos}$ & $91.4 \pm 10.84^{\dagger}$ \\
\hline \multirow[t]{3}{*}{$n=42$} & 9 & $3-5$ mos. & $53.4 \pm 5.83$ \\
\hline & 10 & $6-11 \mathrm{mos}$ & $28.8 \pm 6.33 \S$ \\
\hline & 12 & $1-3$ yrs. & $29.8 \pm 4.36^{\dagger}$ \\
\hline \multirow{5}{*}{$\begin{array}{l}\text { Anticonvulsant therapy } \\
\text { with } \mathrm{PB} \text { and } \mathrm{DPH} \text { " } \\
\quad n=34\end{array}$} & & & \\
\hline & 9 & $1-2 \mathrm{mos}$ & $24.3 \pm 5.07^{\dagger}$ \\
\hline & 6 & $3-5$ mos. & $25.0 \pm 6.61 \ddagger$ \\
\hline & 7 & $6-11 \mathrm{mos}$ & $20.9 \pm 4.49^{\dagger}$ \\
\hline & 12 & $1-3$ yrs. & $14.7 \pm 1.97 \dagger$ \\
\hline
\end{tabular}

\footnotetext{
$*$ Mean \pm S.E.M. $\dagger p<0.005, \quad \ddagger p<0.02, \S p<0.05$.

I Some patients received other anticonvulsants as well in addition to PB and DPH.

All values were obtained by rapid assay. Details of method were described in the text.
}

of PB the serum 25-OH-D levels became lower than the control values $(p<0.05)$ (Table 1). On the other hand, the patients receiving combined anticonvulsant therapy never showed an initial increase of the serum 25-OH-D levels and the values were much lower than the control values during $1-2$ months $(p<0.005)$ (Table 1). One-to-three-year-administration of the combined drugs caused a further decrease of serum 25-OH-D levels and they were significantly lower than those of the PB (group $(p<0.005)$.

\section{Drscussion}

The present study demonstrated that in ambulatory juvenile epileptic patients without physical and psychomotor disturbances, the serum 25-OH-D levels in the PB-treated patients increased transiently soon after administration and then they decreased to the levels lower than those before administration in 6-11 months, while the values of the patients treated with combined drugs markedly reduced during 1-2 months of treatment and the initial rise was not observed.

25-OH-D values determined with the rapid assay method used in this study revealed a good correlation with those of the method of preparative chromatography, although a slightly higher value was obtained. $24,25-(\mathrm{OH})_{2}-\mathrm{D}$, which has the same affinity to binding-protein as 25-OH-D (Haddad et al. 1976) may also be included in the values obtained by the rapid assay, but its concentration is less than one-tenth of 25-OH-D in the human serum. So that, the major part of the value measured by the rapid assay presumably reflects the serum $25-\mathrm{OH}-\mathrm{D}$ level.

There are many reports on the $25-\mathrm{OH}-\mathrm{D}$ values after the long administration of anticonvulsants. (Hahn et al. 1972, 1975a; Stamp et al. 1972) However, there is 
no description concerning the time course of the human serum 25-0H-D after the administration of anticonvulsants. It was revealed that the serum 25-OH-D levels of the epileptic children increased shortly after PB administration. Hahn et al. (1975b) reported that there might be a brief paradoxical rise in serum 25-OH-D of rats after initiation of $\mathrm{PB}$ administration, presumably due to a temporary competitive block of catabolic pathways. On the other hand, the serum 25-OH-D values of the patients receiving $\mathrm{PB}$ and $\mathrm{DPH}$ therapy became much lower than the control values during 1-2 months. The reason of the difference in serum 25-OH-D between the patients treated with single $\mathrm{PB}$ and those treated with combined drugs is not clear at present. It may depend partly on the difference of hepatic microsomal enzyme induction - the rate of conversion of vitamin $\mathrm{D}$ to 25-OH-D - by PB and PB-DPH combination.

Hahn et al. (1972; 1975a) described that the serum 25-OH-D levels decreased both in adults and children receiving long-term anticonvulsant therapy and no differences in serum 25-OH-D levels were observed between the single PB and combined drugs after 3-4 years of anticonvulsant therapy. But most of the patients of rickets precipitated by long-term anticonvulsant therapy had received PB, DPH and other combined medicaments (Richen and Rowe 1970; Stamp et al. 1972; Teotia et al. 1973; Lifschitz and Maclaren 1973; Leonidas et al. 1973; Stamp 1974). But Teotia et al. (1973) reported that a patient treated with $\mathrm{PB}$ alone suffered from rickets after the PB and DPH combination therapy. Accordingly, the administration of $\mathrm{PB}$ and $\mathrm{DPH}$ must be responsible for the rickets in the epileptic children. These facts may be compatible with our results that the anticonvulsant therapy with two drugs caused a decrease in the serum level of $25-\mathrm{OH}-\mathrm{D}$ soon after the initiation of administration of the drugs and the serum 25-OH-D levels in these patients were significantly lower than those in the patients with $\mathrm{PB}$ therapy after 1-3 years. Therefore, PB-DPH combination therapy seems to be prone to cause rickets even in the early stage and certainly more than the single $\mathrm{PB}$ therapy.

\section{Acknowledgments}

This investigation was supported by research grants from the Ministry of Public Welfare.

\section{References}

1) Haddad, J.G., Min, C., Wagate, J. \& Hahn, T.J. (1976) Competition by $24,25-(\mathrm{OH})_{2^{-}}$ $\mathrm{D}_{3}$ in the competitive protein binding radioassay of $25-\mathrm{OH}-\mathrm{D}$. J. clin. Endcr. Metab., 43, 712-715.

2) Hahn, T.J., Hendin, B.A., Scharp, C.R. \& Haddad, J.G. (1972) Effect of chronic anticonvulsant therapy on serum 25 -hydroxycalciferol levels in adults. New Engl. J. Med., 287, 900-904.

3) Hahn, T.J., Hendin, B.A., Scharp, C.R., Boisseau, V.C. \& Haddad, J.G. (1975a) Serum 25-HCC levels and bone mass in children on chronic anticonvulsant therapy.
New Engl. J. Med., 292, 550-554.

4) Hahn, T.J., Halstead, L.R., Scharp, C.R. \& Haddad, J.G. (1975b)..Enhanced biotransformation and biologic efficacy of vitamin $D$ following phenobarbital 
administration in the rat. Clin. Res., 23, $111 \mathrm{~A}$.

5) Holick, M.F. \& Deluca, H.F. (1971) A new chromatographic system for vitamin $\mathrm{D}_{3}$ and its metabolites: Resolution of a new vitamin $\mathrm{D}_{3}$ metabolite. J. Lipid Res., 12, $460-465$.

6) Kruse, R. (1968) Osteopathien bei antiepileptischer Langzeittherapie (Vorläufige Mitteilung). Msch. Kinderheilk., 116, 378-380.

7) Leonidas, J.C., Brill, P.W. \& Waldman, N. (1973) Antiepileptic therapy and rickets in children. Radiology, 109, 409-412.

8) Lifschitz, F. \& Maclaren, N.K. (1973) Vitamin D-dependent rickets in institutionalized, mentally retarded children receiving long-term anticonvulsant therapy. I. A survey of 288 patients. J. Pediat., 83, 612-620.

9) Preece, M.A., O'Riordan, J.L.H., Lawson, D.E.M. \& Kodicek, E. (1974) A competitive protein-binding assay for 25-hyroxycholecalciferol and 25-hydroxyergocalciferol in serum. Clin. chim. Acta, 54, 235-242.

10) Richen, A. \& Rowe, D.J.F. (1970) Distrubance of calcium metabolism by anticonvulsant drugs. Brit. med. J., 4, 73-77.

11) Shimotsuji, T., Seino, Y. \& Yabuuchi, H. (1976) A competitive protein binding assay for plasma 25-hydroxyvitamin $\mathrm{D}_{3}$ in normal children. Tohoku J. exp. Med., 118, 233-240.

12) Stamp, T.C.B. (1974) Effect of long-term anticonvulsant therapy on calcium and vitamin D metabolism. Proc. roy. Soc. Med., 67, 64-68.

13) Stamp, T.C.B., Round, J.M., Rowe, D.J.F. \& Haddad, J.G. (1972) Plasma levels and therapeutic effect of 25-hydroxycholecalciferol in epileptic patients taking anticonvulsant drugs. Brit. med. J., 4, 9-12.

14) Teotia, M., Srendra, D.C.H. \& Teotia, P.S. (1973) Rickets precipitated by anticonvulsant drugs in a child receiving prophylactic vitamin D. Amer. J. Dis. Child., $125,850-852$

15) Tolman, K.G., Jubiz, W., Sannella, J.J., Madsen, J.A., Belsey, R.E., Goldsmith, R.S. \& Freston, J.W. (1975) Osteomalacia associated with anticonvulsant drug therapy in mentally retarded children. Pediatrics, 56, 45-51. 